\title{
Cashing in on Seafood
}

\author{
Stephen Heard \\ Champlin's of Wickford
}

S tephen Heard graduated from the University of Rhode Island in 1970 with a degree in business administration. He started his career by signing up as a management trainee at Woolworth's Department Store in Wellesley, Massachusetts. It didn't take him long to realize he missed his calling: being by the Rhode Island shoreline and employed in the fishing industry. Nearly 35 years later, Stephen is a self-made multimillionaire, having followed both his passion for entrepreneurship and for living his life on the Atlantic coast.

NEJE: Seems like you've had quite a successful financial ride here in beautiful, scenic Rhode Island.

Heard: Please don't make it sound like it was easy, or like it was some rags-to-riches story. My father was a Harvard graduate and never did like the fact that I left Woolworth's to go back to the fish business.

\section{NEJE: Why did you?}

Heard: I've always loved the Rhode Island coastline and I guess the fishing business was in my blood. I worked summers during college in the Wickford Shellfish market where they wholesaled lobsters and hard-shelled clams; it was one of the few seafood markets around here in the 1960s. I put in long hours, but I loved working with the fishermen so the time spent there never bothered me. The folks who depended on the sea for their livelihood were an independent lot, proud men all, and it certainly wasn't an easy life. Yet many of them hung in there and did well. These days, it's much more difficult to make your living from the sea.

I wasn't cut out to be a lobsterman, but I did the next best thing. I quit Woolworth's rather than have the company resettle my family in western Massachusetts working in one of its stores. It would have meant being even further away from the ocean, so I went back to Wickford.

\section{NEJE: Same company, different job?}

Heard: Yes, exactly. As a college graduate, I was given a manager's position, which only means I became responsible for just about everything getting done and wasn't paid overtime. Summers were unbelievably hectic with a peak of 25 employees; winters slowed down some, so we only had 15 employees during the colder months.

NEJE: Somewhere along the line, you went from manager to owner. Few people get rich working for someone else.

Heard: Well, the getting rich part-and it's debatable if that's what I am because I think of myself as comfortable, not rich-certainly didn't happen right away. I had gone to work for Jack McGeough, who bought the Wickford fish market operation in 1968 when it was still pretty much a mom-and-pop operation. Jack really built up the business; he was the hardest workingman I'd ever known, putting in 80 - to 100 -hour weeks on a consistent basis.

Jack taught me a lot. He wasn't always the nicest person to work for, but I saw how he reinvested his money in the business and was singularly focused on expanding the company's physical plant. There were other fish wholesalers up and down the coastline and things were pretty competitive. Fishermen might like dealing with you because they felt they could trust you or there was mutual respect. But they had a family to feed too, so if someone else was paying better than we were for their catch, well, they'd take their business elsewhere. We constantly had to be on our toes. We had to know what was going on every minute of every day, constantly monitoring the fish business because it changed daily.

\section{NEJE: How did you get your shot at running things?}

Heard: After six years of working for Jack, he decided to sell the business to the Prelude Company out of Westport, Massachusetts. Prelude had built up a considerable offshore lobster fleet and they began to acquire four to five wholesale seafood companies in order to integrate their operations vertically. It seemed to be a sound business strategy, but I guess they tried to grow too quickly and ran out of cash. They went bankrupt in 1978.

I was employed at another seafood wholesaler when all this transpired. I approached two people, one an old friend of mine and another a coworker, about buying the Wickford operation; they agreed to go to bankruptcy court with me and try to buy it. Everything had been 
closed up for six months and things were pretty well neglected at the place, but we knew the facility was well built and we felt we could run the operation properly.

\section{NEJE: How did you raise the capital?}

Heard: Pretty standard stuff. We pledged our homes and approached the Small Business Association to guarantee a business loan through our local bank. We raised the incredible sum (back then) of $\$ 350,000$. We paid the bankruptcy court $\$ 210,000$ for the property and that left us with $\$ 140,000$ in working capital. It may seem like a lot of money to hold aside to start up the business, but we knew the reality of the marketplace. Fishermen were paid in cash, either daily if they wanted it, or weekly. The restaurants we were wholesaling the food to in Providence, Boston, New York, and Philadelphia didn't settle their accounts for 50 to 60 days. In a way, as a wholesaler, we were everyone's banker as well.

Not all of our business was wholesale, just most of it. Twenty percent was retail to local individuals. That was a nice cash business. (See company advertisement, page 14.)

We opened for business in June 1979. The first six to twelve months, we hardly took any money out of the business. We each got a small salary; we were all depending on our wives to work and carry our families. My wife, Darlene, was working for the phone company and she was the breadwinner. She didn't mind that at all since she had always believed in me and knew I wanted to be my own boss all along.

NEJE: Did you change the name of the company to something memorable like Heard \& Company?

Heard: No, we retained the same name, Wickford Shellfish Company, because the operation had been around for some 40 to 50 years so everyone around the Wickford-North Kingstown area already knew about it. The smartest move we made at the beginning was to reject an offer by the Old Stone Bank, when it initially gave us the start-up money, to take on a variable or floating rate loan. We wanted to know exactly what our monthly borrowing costs would be so we committed to a 9.5 percent interest rate. Within two years, interest rates had skyrocketed to 16 percent or higher under the Carter administration. If we had gone with the variable rate offer we might not have survived.

NEJE: Partnerships can be tricky. Apparently your experience was very positive.

Heard: I'd say so! I was around 30 but my two partners were in their early 40 s so they had more experience than I did. That really helped. We were all friends and knew each other socially before starting the business together. We agreed to split up assignments so each of us could take a piece of the operation that related best to our strong points. I handled wholesale accounts, another partner took the retail piece and scheduled the employee shifts, and my second partner took over the administrative chores. We avoided mistakes that other partnerships have made by communicating openly, trusting each other, and working huge hours-usually 80 to 90 hours a week. That's about 15-hour days if you figure each of us took a day off during the week.

It meant sacrificing time at home, and Darlene for a while told me she was concerned that I had become a slave to the business. I was never home during the summer months, that's for sure. It was our busiest time and it was essential all three of us put in the hours required to make our operation successful. Over the years, we bought a couple of vacation homes but we eventually sold them because we never had time as a family to use them. I was just too busy.

\section{NEJE: Any other bumps along the way?}

Heard: Actually, no. The company always showed a profit so finances were never a big issue. Our fish operation became known as a good payer so our reputation grew and grew. It was exhausting work, but it paid off. After about six years of this intense effort, a local businessman who owned a home heating oil operation was looking to diversify, so he offered to buy us out.

Negotiations dragged on for some six to nine months and our prospective buyer threatened to walk away and buy another fish business. However, that deal fell through so he came back to us and sweetened his offer. We sold him the business for more than $\$ 1$ million, which seemed like a fortune back in 1984. We had built up the seafood operation from zero to more than $\$ 5$ million in yearly revenues with our own trucks leaving every night to New York City, New Jersey, or Philadelphia. We really accomplished something!

\section{NEJE: So this meant early retirement for you?}

Heard: Hardly. While my partners and I built up the Wickford site, we had purchased three more wholesale seafood businesses in Wickford, Tiverton, and Warwick. As a group, we started the Tiverton Shellfish Company. This operation, along with Warwick Cove Shellfish, was one of the largest clam dealers in Rhode Island.

We were constantly looking to expand our revenue base, whether through internal growth or through acquisitions. However, we always insisted that any business 
we purchased had to include owning real estate. Since we knew we weren't going to be in business forever, we believed that holding a hard asset like real estate, especially waterfront property, would be a good investment. And we never had to borrow money again through the SBA. We only acquired other companies if we could fund it internally.

So "retirement" meant I only had to take care of three businesses. However, since we had added a new partner during one of our acquisitions, instead of working six days a week, I now only worked three days per week. Eventually, one of my original partners decided he had had enough of the fish business and left for Florida. The second original partner stepped away from day-to-day operations to manage his own lobster boats.

NEJE: So by the late 1980s, you had three wholesale clam operations keeping you busy part of the time. Apparently, we're not finished with your entrepreneurial endeavors.

Heard: Right you are. I wasn't really happy being just in my late-30s and working part-time. My wife and I had purchased a number of investment properties around the area, but these weren't keeping me very busy either. So, when Jimmy Champlin wanted to retire and sell his wholesale seafood business along with his well-known restaurant in Galilee, about 20 minutes driving time from Wickford, I was immediately interested.

NEJE: Let's see if I understand this correctly. You made money selling your first business, had interests in three others, owned investment properties around the town of Wickford, and you still had the motivation to throw yourself into an even bigger venture?

Heard: Yes, but think of it this way: As an entrepreneur, I had no 401(k) plan, no IRAs, no safety net at all. So buying rental properties and buying or selling businesses became my only way to put together enough money for my daughters' college educations and for the future. In no way did I have enough money to retire on before I bought into Champlin's.

\section{NEJE: Did you have the funding to buy Champlin's your- self?}

Heard: Not even close. With two of the original partners and a third who had been part of the Warwick Cove operation, we put together an offer for Champlin's and Jimmy Champlin accepted it. We sold two of our three small clam operations and put everything we had into the business. Jimmy held most of the financing. We paid him $\$ 1$ million for his business but only had to provide
$\$ 200,000$ in cash since he was willing to hold a 20-year note for $\$ 800,000$. Then the three of us ponied up an additional $\$ 250,000$ in working capital and we were on our way.

We made sure we kept the restaurant manager as our key employee since none of us had been in the restaurant business before this. He was young and very talentedexactly what we needed to help us learn the front-end operation. We opened officially in March 1990 but we worked in the business for three months before it changed hands so we could introduce ourselves to the fishermen and to the retail customers. Consistency of service was critical to getting a running start.

The restaurant's location was ideal. Even though it's pretty much a seasonal business, running from Memorial Day through to Columbus Day, we had a waterfront location and we were near the ferry terminal to Block Island. We knew we could stay open from November to April and still draw some business.

NEJE: We wouldn't be surprised to learn that you grew Champlin's business as well.

Heard: You bet we did. In the 10 years I co-owned Champlin's, we expanded from seating 60 customers to up around 300 . We expanded the inside tables by removing some office space and then built an outside deck with a canopy that can seat 150 customers during warmer weather. Maybe we didn't know much about how to run a restaurant when we started out, but we all figured it would have to work if we just offered the best, freshest seafood people could eat at reasonable prices.

Business boomed. We served upwards of 1,200 meals a day using only window service. We didn't employ waitpeople. My two daughters were the "deck kids" who cleaned up after the customers were finished with their meals. Our wives worked on the cash registers or in the kitchen.

NEJE: How did you convince your wife to work in the business?

Heard: Oh, that was easy. If Darlene wanted to see me, she had to work at Champlin's! We had no real summer vacations since it was all taken up with work. In fact, now that I've just sold my interest in Champlin's to my other partners, this coming summer will be the first one in 35 years I will be able to enjoy just being out on my boat.

\section{NEJE: Why did you decide to cash out?}

Heard: It was time for me to slow down. I was getting burned out and I could see my other partners were too. They were cutting back their hours and I saw that as the 
handwriting on the wall. Working seven days a week was a real killer. Plus, there were too many kids in the next generation for all of them to work in the restaurant; someone had to bow out. Finally, I couldn't see my legacy as getting my daughters involved in something that would require 70 to 80 hours of commitment a week. It didn't seem fair.

I structured a five-year payout in 1999 with my partners and I just received my last check from them. This deal included selling my interest in a retail seafood market in Wickford we had purchased together in 1996 and renamed "Champlin's of Wickford." We traded in on the Champlin brand name and got immediate customer credibility.

NEJE: What were the negotiations like? Things can get pretty sticky with evaluating the value of a business operation among partners.

Heard: I know it can, but remember, I've had a close personal relationship with all my partners. We were truly friends and still are today. We came up separately with our sense of what the business was worth and the numbers were pretty close. We had an accountant to offer advice, but it all came down to a handshake. In all the years I've been in business, we have never had anything written down. No contracts, no partnership agreements.

NEJE: Since you're vibrant and still shy of 60, what comes next?

Heard: Well, I've been thinking that over. I'm itching to get back into some type of entrepreneurial activity. I only know the seafood business, so I imagine it would be related in some way to that and I know I want to involve my daughters and no one else. I love owning real estate and I've learned waterfront property beats owning anything else.

I know there are downsides. The rules and regulations you have to follow as a small business owner today are quite complex and can be expensive. Worker's compensation and health insurance premiums are going through the roof and the state government of Rhode Island has barely reacted to this crisis. It seems everyone has a hand in your pocket even before you open your doors and find- ing people who are willing to work hard has become a daunting challenge.

Yet I find the entrepreneurial life a great way to live. At the end of the day when you're bone tired, it's just great to see a full cash register and remember the long lines of customers waiting patiently to give you their money in exchange for an honest product. I didn't see my daughters much when they were growing up. If we go into business together, it will give me another chance to do things better and spend more time with them. Life goes awfully quickly.

$-L . W$.

Few yars ago, t'was
a real purty fish market
here in Wickford Town.
water. She was down
the road a piece from
the village 'bout as fur
as a hen chicken could

